\title{
LITERASI MULTIKULTURAL KOMUNITAS ETNIK KAMPUNG RAMA KECAMATAN PANAKUKANG KOTA MAKASSAR
}

\author{
Tuti Bahfiarti $^{1 *}$, Arianto1, Jeanny Maria Fatimah'1, Muhammad Farid ${ }^{1}$ \\ ${ }^{I}$ Departemen Ilmu Komunikasi, Fakultas Ilmu Sosial dan Ilmu Politik, Universitas Hasanuddin, Makassar, \\ Indonesia \\ *Penulis Korespondensi: tutibahfiarti@unhas.ac.id
}

\begin{abstract}
Abstrak
Komunitas etnik Kampung Rama dominan beretnik Toraja terletak di Kecamatan Panakukang Kota Makassar. Permasalahan mitra komunitas etnik Kampung Rama Kelompok mayoritas adalah etnik Toraja dan kelompok minoritas adalah etnik Bugis, etnik Makassar, etnik Mandar, dan etnik Jawa. Kelompok mayoritas dan minoritas berbeda agama, nilai, kepercayaan, dan adat istiadat harus saling memahami. Tujuannya memaksimalkan pengetahuan, sikap dan perilaku dalam menerima perbedaan sebagai keberagaman bangsa. Metode ini dapat meningkatkan karakter sikap demokratis, pluralis, dan humanis pada masyarakat komunitas Etnik Kampung Rama. Tahapan metode yakni, pertama, pembuatan karya audio visual pendidikan multikultural; kedua, kegiatan pengajaran dan pelatihan; ketiga, pemutaran audio visual multikultural, dan keempat : hasil pretest dan postest literasi multikultural. Nilai postest lebih tinggi dari pretest, seperti pemahaman dan keterbukaan masyarakat terhadap perbedaan suku, agama, dan ras. Cara pengambilan keputusan dan peran aktif pada perbedaan suku mengalami peningkatan hasil dari pretest dan postest. Persepsi dan pandangan masyarakat terhadap kebebasan beragama menunjukkan hasil sama yakni $100 \%$.
\end{abstract}

Kata kunci: Literasi Multikultural; Etnik Toraja; Kampung Rama; Kecamatan Panakukang; Kota Makassar.

\begin{abstract}
The dominant ethnic Rama village of Toraja ethnic is located in Panakukang District, Makassar City. Problems with the Rama Kampung Rama ethnic community majority groups are Toraja and minority groups are Bugis, Makassarese, Mandarese and Javanese. Majority and minority groups with different religions, values, beliefs and customs must understand each other. The aim is to maximize knowledge, attitudes and behavior in accepting differences as a diversity of nations. This method can improve the character of democratic, pluralist and humanist attitudes. The stages of the method are, first, the making of audio visual works in multicultural education; second, teaching and training activities; third, multicultural audio-visual playback, and fourth: multicultural literacy pretest and posttest results. The posttest score is higher than the pretest, such as people's understanding and openness to differences in ethnicity, religion, and race. The method of decision making and the active role in tribal differences have increased the results of the pretest and posttest. Public perceptions and views on religious freedom show the same results, namely $100 \%$.
\end{abstract}

Keywords: Multicultural Literacy; Toraja Ethnic; Kampung Rama; Panakukang District; Makassar city.

\section{PENDAHULUAN}

Indonesia merupakan negara yang memiliki kemajemukan ditandai dengan perbedaan suku bangsa, ras, bahasa, adat istiadat, agama dan budaya. Keberagaman budaya masyarakat Indonesia menyebabkan mereka sangat multikultural karena latar belakang agama dan budaya yang beragam. Indonesia merupakan bangsa multikultural dan majemuk, yang secara konseptual multikuluralisme mengandung unsur keberagaman agama dan budaya, serta terkandung nilainilai kesedarajatan. Oleh karena itu, multikulturalisme harus dilakukan secara berkelanjutan untuk menanamkan nilai-nilai perbedaan dalam keberagaman pada generasi bangsa.

Negara multikultural terbesar di dunia adalah Indonesia, ditandai dengan kelompok etnis, suku, agama, budaya dan kepercayaan. Berdasarkan data Indonesia sebagai Negara kepulauan yang terdiri dari 13.000 pulau besar, 300 suku, dan 200 bahasa. Agama yang dianut masyarakat Indonesia juga beragam, yakni Islam, Kristen, Katolik, Hindu, Budha, dan Konghuchu, serta berbagai macam aliran kepercayaan (Nurcahyono, 2018). Konsep multikultural memiliki dampak positif 
karena keberagaman memperkaya nuansa budaya dalam masyarakat. Namun, jika tidak ada kesalahpahaman antara budaya dan agama yang berbeda berpotensi menimbulkan konflik Suku, Agama, Ras, dan Antargolongan (SARA).

Berdasarkan hal tersebut, diperlukan pendidikan multikultural sebagai upaya meminimalisir konflik antar etnik, agama, kepercayaan, dan lain-lain. Dengan literasi pendidikan multikultural pemberdayaan masyarakat yang majemuk dan heterogen untuk saling saling memahami dan menghormati perbedaan dapat dikembangkan (Tilaar, 2004). Dalam masyarakat multikultural perbedaan merupakan kekayaan budaya yang sangat penting, karena ada perilaku saling menghargai dan saling menghormati antar budaya dan antar agama.

Keberagaman budaya dan agama juga terlihat di Kampung Rama. Berdasarkan data pengamatan menunjukkan bahwa komunitas Etnik Kampung Rama didominasi oleh masyarakat Etnik Toraja yang berinteraksi langsung dengan Etnik Bugis, etnik Makassar, etnik Mandar, dan etnik Jawa. Masyarakat Etnik Toraja yang berlokasi di Jalan Dirgantara, merupakan bagian dari masyarakat Ujung Pandang Timur Tello Batua yang tahun 1990 hanya berjumlah 300 kepala keluarga. Namun, saat ini anggota masyarakat Kampung Rama terdiri dari 913 kepala keluarga dengan jumlah jiwa 2.555 orang.

Analisis situasional bertolak dari semangat untuk menerapkan paradigma multikultural kepada masyarakat etnik Toraja. Pandangan multikultural dalam suatu masyarakat pluralisme sangat urgen dilakukan, khususnya di Kecamatan Panakukang Kota Makassar. Hal ini bertujuan meminimalkan konflik antar etnis dan antar agama yang berpotensi terjadi dalam lingkup masyarakat mayoritas dan minoritas. Kelompok mayoritas harus menghargai dan menerima perbedaan terhadap kelompok minoritas. Demikian pula sebaliknya, kelompok minoritas harus mampu berempati dan menempatkan diri dalam proses interaksi dan komunikasi dengan kelompok mayoritas.

Berdasarkan data keberagaman budaya dan agama maka perlu peningkatan komunitas Etnik Toraja yang memerlukan pola-pola literasi pendidikan multikultural dalam setiap kegiatan masyarakat. Tujuannya membangun cara hidup multikultural untuk memperkuat wawasan kebangsaan keanggotaan mereka. Literasi dini multikultural dapat meminimalkan konflik sosial yang awalnya bersumber pada ketidakpahaman terhadap perbedaan agama, nilai, kepercayaan dan adat istiadat. Legitimasi pemahaman perbedaan antarbudaya dapat meminimalkan konflik sosial di kalangan masyarakat perkotaan seperti di Kota Makassar.

Kenyataan menunjukkan bahwa literasi pendidikan multikultural di kalangan kelompok mayoritas dan minoritas menjadi salah satu solusi untuk merekatkan kehidupan antar umat beragama di Kota Makassar. Kondisi ini untuk meminimalkan konflik yang dalam sejarah pernah terjadi di Kota Makassar, misalnya tanggal 15 September 1997 Benny Karre, beretnik Tionghoa membunuh anak berusia 9 tahun, pelaku akhirnya mati dikeroyok massa. Isu Suku Agama Ras dan Antargolongan yang dihembuskan mengakibatkan amuk massa memporak-porandakan rumah dan bangunan pelaku, merusak dan membakar rumah warga etnik Tionghoa. Kasus lainnya insiden penikaman membabi buta Petrus Bolu, 30 tahun warga Nusa Tenggara Timur di depan Makassar Town Square mengakibatkan tiga korban. Kasus seperti di atas dapat diminimalkan dengan melakukan literasi pendidikan multikultural antar etnik di Kota Makassar.

Etnik Toraja dan etnik Bugis, serta etnik Makassar, etnik Mandar, etnik Jawa dan etnik lain yang berbeda diharapkan hidup saling menghargai, dan saling menghormati. Namun, jika isu perbedaan etnik dan agama disebarkan dapat menimbulkan ketegangan. Di berbagai tempat terjadinya konflik, massa yang mengamuk adalah kelompok mayoritas; sedangkan kelompok yang ditekan dan mengalami kerugian fisik dan mental yang minoritas. Kelompok mayoritas merasa berkuasa atas daerah yang didiami lebih dari kelompok minoritas. Karena itu, di beberapa tempat orang kelompok minoritas sering mengalami kerugian fisik, seperti, pengrusakan rumah dan pembakaran gedung-gedung ibadah.

Semangat pendidikan multikultural akan memperkuat persatuan dan kesatuan bangsa yang harmonis. Secara teoritik, multikultural mengandaikan adanya kesadaran internal yang inklusif dan mengejawantah dalam perilaku sosial kemasyarakatan. Sebuah kesadaran yang mengikat kecerdasan emosi setiap etnisitas yang memiliki perbedaan namun tetap saling menghargai antara satu sama lainnya. Kemampuan berinteraksi, beradaptasi bahkan mengadopsi unsur-unsur dari kebudayaan berasal dari masing-masing etnik yang berbeda dapat memperkaya dan menumbuhkan hubungan harmonis antara masyarakat etnik Toraja dengan etnik-etnik yang berbeda di Kecamatan Panakukang Kota Makassar.

Pendidikan multikultural sangat strategis untuk mengelola kemajemukan secara kreatif, sehingga konflik yang muncul sebagai dampak dari transformasi dan reformasi sosial dapat dikelola secara cerdas dan menjadi bagian dari pencerahan kehidupan bangsa ke depan. Pendidikan agama juga harus berwawasan multikultural. Wacana literasi pendidikan multikultural tidak berpretensi menghilangkan nilai-nilai partikular agama.

Partikularitas suatu agama hanya diperuntukkan bagi pemeluk agama itu saja, dan tidak dipaksakan untuk pemeluk agama lain. Dalam menghadapi pemeluk agama yang berbeda, setiap idividu dan kelompok harus dipegang adalah nilai-nilai universal berupa keadilan, kemanusiaan, kesetaraan, berbuat baik dan saling 
mencintai sesama, kejujuran, tanpa memandang perbedaan.

Selanjutnya, literasi pendidikan multikultural boleh dikatakan sebagai sebuah proses pengembangan sikap dan tata perilaku seseorang atau sekelompok orang dalam usaha mendewasakan manusia melalui upaya pengajaran, pelatihan, proses, perbuatan, dan cara-cara mendidik yang menghargai pluralitas dan heterogenitas secara humanistik. Diharapkan agar peserta didik memiliki karakter yang kuat untuk bersikap demokratis, pluralis, dan humanis.

Tujuan kegiatan menstimuli, mengarahkan, dan mempersuasi melalui literasi pendidikan multikultural komunitas etnik Kampung Rama sebagai kelompok minoritas serta melibatkan kelompok mayoritas yakni etnik Bugis dan etnik Makassar yang juga berdomisili di wilayah tersebut. Berwawasan multikultural memberikan kontribusi nyata terhadap agenda demokratisasi dan nondiskriminasi. Perhatian yang besar terhadap equalitas (persamaan) dan nondiskriminasi kaum minoritas telah menghubungkan multikultural dengan demokrasi. Bukankah sisi terpenting dari nilai demokrasi adalah keharusan memperlakukan berbagai kelompok atau individu yang berbeda tanpa diskriminasi.

\section{METODE}

Sasaran pengabdian pada masyarakat ini adalah menstimuli, mengarahkan, dan mempersuasi program multikulturalisme sebagai suatu proses belajar yang mengubah dari seseorang yang tidak tahu menahu diri dan lingkungannya menjadi lebih tahu dan memahami. Selanjutnya, pemahaman literasi pendidikan multikultural dalam upaya peningkatan pengetahuan dan pemahaman konsepsi praktis multikultural bagi komunitas etnik Kampung Rama dan masyarakat etnik Bugis dan etnik Makassar. Misalnya, perubahan pengetahuan, sikap, dan perilaku, mampu memberikan perhatian atau perlakuan sama pada perbedaan agama, nilai, kepercayaan, dan adat istiadat yang ada di lingkungannya.

Metode ini bertujuan untuk menstimuli, mengarahkan, dan mempersuasi program pendidikan multikulturalisme yang digunakan untuk adalah:

Pertama, metode pengujian pretest dan postest sebelum dan setelah dilakukan menstimuli, mengarahkan, dan mempersuasi Komunitas Etnik Kampung Rama. Tujuannya untuk mengetahui dan menganalisis data awal dan akhir keberhasilan program pengabdian kepada masyarakat yang bertujuan mengubah pengetahuan, sikap dan perilaku saling menghargai budaya dan agama.

Kedua, metode ceramah yang dimaksud adalah ceramah dengan kombinasi metode yang bervariasi. Ceramah yang cenderung interaktif, yaitu melibatkan anggota komunitas etnik Kampung Rama dan etnik Bugis dan etnik Makassar yang berdomisili di lingkungan yang sama.
Ketiga, demonstrasi adalah metode yang digunakan untuk membelajarkan peserta pelatihan dengan cara menceritakan dan memperagakan suatu langkahlangkah pengerjaan sesuatu, misalnya akibat bentrok antar etnik dan kesalahpahaman budaya.

Keempat, curah Pendapat (Brain Storming), metode curah pendapat adalah suatu bentuk diskusi dalam rangka menghimpun gagasan, pendapat, informasi, pengetahuan, pengalaman, melibatkan anggota komunitas etnik Kampung Rama dan etnik Bugis, etnik Makassar yang berdomisili di lingkungan yang sama.

Kelima, metode pemberdayaan program antarbudaya yakni memberikan pendampingan terhadap anggota Komunitas Etnik Kampung Rama dan Etnik Bugis Makassar yang berdomisili di lingkungan yang sama. Tujuannya untuk lebih melihat bentuk kegiatan yang mereka lakukan setelah dilakukannya pelatihan literasi pendidikan multikultural.

Metode-metode pelaksanaan kegiatan bertujuan memberikan solusi permasalahan pada mitra melalui literasi pendidikan multikultural. Metode-metode pelaksanaan kegiatan adalah menstimuli, mengarahkan, dan mempersuasi komunitas etnik adar bersikap dan berperilaku multikultural. Metode ini dapat menjadi proses transfer pengetahuan praktis pentingnya literasi pendidikan multikultural sebagai agen perubah melalui suatu proses ketidak setaraan dan diskriminasi guna mewujudkan suatu peningkatan pengetahuan dan pemahaman keadilan dan kesetaraan, proses perubahan yang berkelanjutan.

\section{HASIL DAN PEMBAHASAN}

Pengabdian Kemitraan Masyarakat merupakan bagian dari permasalahan yang sering terjadi dalam masyarakat multikultural. Kondisi ini terlihat di Kampung Rama yang mayoritas penduduknya beretnik Toraja. Kehidupan masyarakat Kampung Rama yang berinteraksi antara masyarakat yang berbeda Etnik, Mislanya Etnik Bugis, Etnik Makassar, Etnik Jawa, dan lain-lainnya. Dalam kehidupan keagamaan etnik Toraja dengan etnik-etnik lainnya tidak ada perbedaan yang tajam, tetapi pada tataran realitas sosial, sering terjadi adanya perbedaan budaya dan agama yang mendasar, terutama dalam multikultural.

Pengabdian masyarakat literasi multukultural dan pendidikan multikultural tidak berpretensi menghilangkan nilai-nilai partikular suatu etniknya. Namun, menerima perbedaan sebagai bagian dari kemajemukan yang bersifat positif. Luarannya adalah pengembangan sikap dan tata perilaku seseorang atau sekelompok dalam mendewasakan manusia yang menghargai pluralitas, heterogenitas secara humanistik.

Tujuannya adalah peserta/anggota komunitas Etnik Kampung Rama menerima perbedaan dan menghindari pemicu konflik antarbudaya. Literasi dan pendidikan multikultural memberikan kontribusi nyata terhadap agenda demokratisasi dan nondiskriminasi. Perhatian yang besar terhadap equalitas (persamaan) dan nondiskriminasi kaum minoritas telah menghubungkan 
multikultural dengan demokrasi. Semangat pendidikan keberagaman dan kemajemukan dapat memperkuat persatuan dan kesatuan bangsa, meliputi 3 tahapan :

Tahapan Pertama : Pembuatan Karya Audio Visual Pendidikan Multikultural

Penyelenggaraan kegiatan literasi multikultural ini dilakukan pembuatan karya audio visual yang menggambarkan pentingnya saling memahami antara perbedaan antar etnik yang ada. Karya ini melibatkan 6 orang mahasiswa yang memberikan ide kreatif untuk menggugah komunitas etnik Kampung Rama yang mayoritas beretnik Toraja untuk lebih memahami dan saling menghargai di antara mereka meskipun berbeda etnik.

\section{Tahapan Kedua : Kegiatan Pengajaran dan Pelatihan}

Penyelenggaraan kegiatan pengajaran dan pelatihan yang bertemakan pendidikan literasi multikultural yang bertujuan meningkatkan perubahan pengetahuan (knowledge) dan sikap (attitude). Kegiatan workshop menggunakan metode ceramah yang dimaksud disini adalah ceramah dengan kombinasi metode yang bervariasi ceramah yang cenderung interaktif, yaitu melibatkan peserta melalui adanya tanggapan balik atau perbandingan dengan pendapat dan pengalaman komunitas Etnik Kampung Rama yang telah didata sebanyak 40 orang. Penyelenggaraan kegiatan workshop ini berlangsung beberapa tahapan, yakni Pelaksanaan dan Evaluasi. Kegiatan ini pada bulan JuliAgustus 2019 tempat Kampung Rama Kecamatan Panakukang Kota Makassar.

Kegiatan pendidikan literasi multikultural diikuti 40 etnik Toraja yang berdomisili di Kampung Rama. Kegiatan ini bertujuan untuk memberikan pengetahuan dan transfer pentingnya menumbuhkan literasi multikultural dalam keseharian mereka. Pemahaman terhadap literasi multikultural dapat memberikan pemahaman bahkan perubahan perilaku bagi keberagaman etnik yang ada di Kampung Rama. Tujuannya peserta/anggota komunitas Etnik Kampung Rama menerima perbedaan dan menghindari pemicu konflik antarbudaya. Literasi dan pendidikan multikultural memberikan kontribusi nyata terhadap agenda demokratisasi dan nondiskriminasi.

Hasil capaian kegiatan pelatihan dan pendampingan literasi dan pendidikan multikultural bekerjasama dengan komunitas Etnik Toraja Kampung Rama, pertama tokoh dan opinion leader dalam memberikan transfer pengetahuan pentingnya literasi dan pendidikan multikultural. Bentuk role play motivasi masyarakat untuk memahami perbedaan budaya. Pembelajaran "konflik, stereotipe, dan prasangka" melalui interaktif dengan melibatkan masyarakat etnik Toraja secara langsung bertanya dan menjawab pertanyaan pengetahuan umum. Bentuk kegiatan pelatihan dan pendampingan literasi multikultural yang dilakukan pada komunitas Etnik Toraja Kampung Rama, dapat di lihat pada gambar 1 berikut :

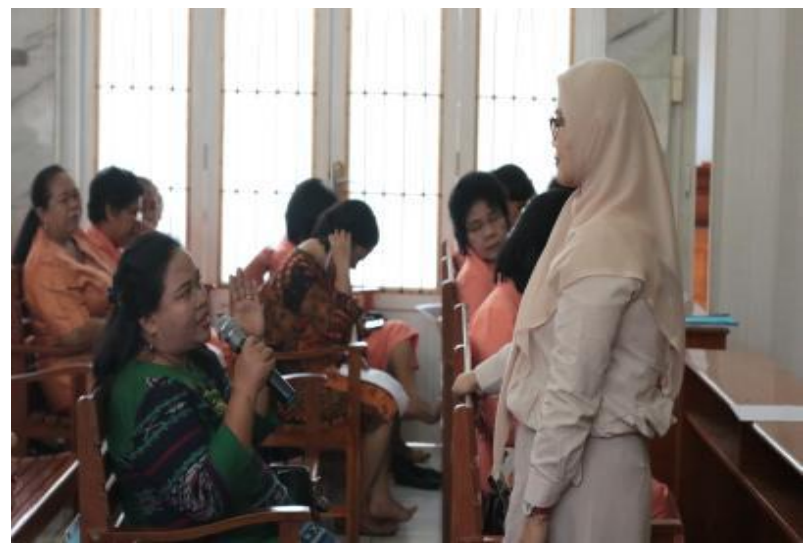

Gambar 1. Kegiatan Pelatihan Literasi Multikultural.

Tahapan Ketiga : Pemutaran Animasi Iklan Audio Visual Multikultural

Selanjutnya, rangkaian kegiatan Pengabdian Kemitraan Masyarakat ini juga melibatkan mahasiswa Mahasiswa Departemen Ilmu Komunikasi Angkatan 2016 dan 2017 memutarkan Animasi Edukatif pendidikan dan literasi multikultural tentang pentingnya memahami perbedaan budaya.

Tujuan dari pemutaran Animasi Edukatif pendidikan dan literasi multikultural ini agar proses transfer pengetahuan dengan segmen khalayak lebih cepat dipahami dibandingkan dengan metode ceramah. Keterlibatan langsung masyarakat dalam proses pelatihan dan pendampingan ini lebih cepat dimengerti dan dipahami.

\section{Tahapan Keempat : Hasil Pretest dan Postest Literasi Multikultural}

Pretest merupakan syarat awal yang dilakukan sebelum pelaksanaan pelatihan dan pendampingan pendidikan dan literasi multikultural yang bertujuan untuk menganalisis dan membandingkan pengetahuan awal dan akhir dari peserta terhadap perubahan pengetahuan dan sikap mereka setelah diterpakan pesan-pesan pendidikan dan literasi multikultural.

Berdasarkan analisis data hasil pretest dan postest menunjukkan bahwa pretest merupakan syarat awal yang dilakukan sebelum menstimuli, mengarahkan, dan mempersuasi pendidikan dan literasi multikultural dalam mengembangkan dan menumbuhkan kesdaran multikultural pada komunitas Etnik Toraja Kampung Rama. Berdasarkan jawaban komunitas Etnik Toraja sebelum diterpakan pesan dalam pelatihan dan pendampingan pendidikan dan literasi multikultural di Kecamatan Panakukang Kota Makassar SulawesiSelatan, seperti tabel 1 berikut ini : 
Tabel 1. Pemahaman Masyarakat terhadap Perbedaan Suku, Agama, dan Ras.

\begin{tabular}{|l|c|c|c|c|}
\hline \multirow{2}{*}{$\begin{array}{c}\text { Pemahaman } \\
\text { Masyarakat }\end{array}$} & \multicolumn{2}{|c|}{ Pretest } & \multicolumn{2}{c|}{ Postest } \\
\cline { 2 - 5 } & F & \%) & F & \%) \\
\hline Sangat Setuju & 35 & 87,5 & 40 & 100 \\
\hline Kurang Setuju & 5 & 12,5 & 0 & 0 \\
\hline Tidak Setuju & 0 & 0 & 0 & 0 \\
\hline Jumlah & 40 & 100 & 40 & 100 \\
\hline
\end{tabular}

Sumber : Hasil Olahan Kuesioner, 2019.

Data tabel 1, di atas menunjukkan bahwa masyarakat Kampung Rama memiliki nilai postest lebih tinggi sebanyak $100 \%$ dibandingkan saat pretest sebanyak $87,5 \%$. Hasil tersebut mengindikasikan bahwa masyarakat Indonesia adalah masyarakat yang beragam baik dari suku, agama, ras hingga agama maka dari itu kita harus hidup berdampingan tanpa mempermasalahkan keragaman tersebut. Selanjutnya, cara bersikap dan berperilaku terbuka terhadap setiap adat dan istiadat daerah lain tanpa melupakan adat dan istiadat di daerah asal. Setelah dilakukan pendampingan melalui pengabdian masyarakat berbasis pesan-pesan pendidikan dan literasi multikultural menunjukkan hasil seperti Tabel 2 berikut :

Tabel 2. Keterbukaan Masyarakat terhadap Perbedaan Adat Istiadat.

\begin{tabular}{|l|c|c|c|c|}
\hline \multirow{2}{*}{$\begin{array}{c}\text { Keterbukaan } \\
\text { Masyarakat }\end{array}$} & \multicolumn{2}{|c|}{ Pretest } & \multicolumn{2}{c|}{ Postest } \\
\cline { 2 - 5 } & F & \%) & F & \%) \\
\hline Sangat Terbuka & 35 & 87,5 & 40 & 100 \\
\hline Kurang Terbuka & 5 & 12,5 & 0 & 0 \\
\hline Tidak Terbuka & 0 & 0 & 0 & 0 \\
\hline Jumlah & 40 & 100 & 40 & 100 \\
\hline
\end{tabular}

Sumber : Hasil Olahan Kuesioner, 2019.

Data tabel 2, di atas menunjukkan bahwa masyarakat Kampung Rama memiliki nilai postest lebih tinggi sebanyak $100 \%$ dibandingkan saat pretest sebanyak 87,5\%. Hasil tersebut mengindikasikan bahwa masyarakat Kampung Rama yang dominan beretnik Toraja dan beragama Kristen Protestan memiliki sikap dan perilaku terbuka setelah mendapatkan workshop dan pendampingan pendidikan multikulturalis. Masyarakat yang menjadi subjek menunjukkan setiap adat dan istiadat daerah lain tanpa melupakan adat dan istiadat di daerah asal. Selanjutnya, dalam pengambilan suatu keputusan terhadap kepentingan bersama selalu dilakukan dengan bermusyawarah. Setelah dilakukan pendampingan melalui pengabdian masyarakat berbasis pesan-pesan pendidikan dan literasi multikultural menunjukkan hasil sebagai berikut :
Tabel 3. Cara Pengambilan Keputusan Masyarakat terhadap Kelompok Berbeda Suku.

\begin{tabular}{|c|c|c|c|c|}
\hline $\begin{array}{c}\text { Cara Pengambilan } \\
\text { Keputusan }\end{array}$ & \multicolumn{2}{|c|}{ Pretest } & \multicolumn{2}{c|}{ Postest } \\
\cline { 2 - 5 } & F & $\mathbf{\% )}$ & F & $(\%)$ \\
\hline Sangat Terbuka & 35 & 87,5 & 40 & 100 \\
\hline Kurang Terbuka & 5 & 12,5 & 0 & 0 \\
\hline Tidak Terbuka & 0 & 0 & 0 & 0 \\
\hline Jumlah & 40 & 100 & 40 & 100 \\
\hline
\end{tabular}

Sumber : Hasil Olahan Kuesioner, 2019.

Data tabel 3 di atas menunjukkan bahwa masyarakat Kampung Rama memiliki nilai postest lebih tinggi $100 \%$ dibanding data pretest sebanyak $87,5 \%$, setelah dilakukan pendampingan melalui pengabdian masyarakat berbasis pesan-pesan pendidikan dan literasi multikultural. Nilai data pretest lebih dominan kurang terbuka sebanyak $67,5 \%$.

Hasil tersebut mengindikasikan bahwa masyarakat Kampung Rama yang dominan beretnik Toraja dan beragama Kristen Protestan pada awalnya masih cenderung kurang terbuka dalam proses pengambilan keputusan yang melibatkan masyarakat Kampung Rama yang berbeda etnik, seperti etnik Bugis, etnik Makassar, dan etnik Jawa. Namun, setelah dilakukan pendidikan literasi multikultural hasil postest menunjukkan data peningkatan $82,5 \%$.

Hal ini mengindikasikan terjadi perubahan pola pikir dalam berinteraksi dan berkomunikasi dengan masyarakat multikultural yang berbeda budaya, keyakinan, nilai dan agama. Khususnya cara pengambilan keputusan dalam hidup bermasyarakat dengan etnik yang berbeda, misalnya etnik Bugis, etnik Makassar, dan etnik Jawa yang mayoritas tinggal di Kampung Rama. Selanjutnya, peran aktif atau tingkat partisipasi dalam kegiatan pembelajaran selalu menggunakan metode diskusi, aktif berperan serta, bermusyawarah, seperti tabel 4 berikut :

Tabel 4. Peran Aktif Masyarakat terhadap Interaksi Kelompok Berbeda Suku.

\begin{tabular}{|c|c|c|c|c|}
\hline \multirow{2}{*}{$\begin{array}{c}\text { Peran Aktif } \\
\text { Masyarakat }\end{array}$} & \multicolumn{2}{|c|}{ Pretest } & \multicolumn{2}{c|}{ Postest } \\
\cline { 2 - 5 } & F & \%) & F & $(\%)$ \\
\hline Sangat Aktif & 0 & 0 & 33 & 82,5 \\
\hline Kurang Aktif & 25 & 62,5 & 7 & 17,5 \\
\hline Tidak Aktif & 15 & 37,5 & 0 & 0 \\
\hline Jumlah & 40 & 100 & 40 & 100 \\
\hline
\end{tabular}

Sumber : Hasil Olahan Kuesioner, 2019.

Data tabel 4 di atas menunjukkan bahwa masyarakat Kampung Rama dari aspek peran aktif berinteraksi dan menyelesaikan permasalahan kemasyarakatan selalu menggunakan metode diskusi, aktif berperan serta, bermusyawarah menunjukkan hasil kurang rendah $62,5 \%$ dan tidak aktif sebanyak 37,5\% tidak saling bertukar informasi dalam menyelesaikan permasalahan melalui jalur diskusi dan musyawarah. Masyarakat etnik Kampung Rama, khususnya etnik Toraja memiliki 
kecenderungan berdasarkan data pretest berinteraksi dengan komunitas sesama etnik dan agama yang sama.

Data setelah dilakukan pendampingan melalui pengabdian masyarakat berbasis pesan-pesan pendidikan dan literasi multikultural memiliki nilai postest lebih tinggi sebanyak $82,5 \%$ yang berperan aktif berinteraksi dan menyelesaikan permasalahan pemasyarakatan selalu menggunakan metode diskusi, aktif berperan serta, bermusyawarah. Selanjutnya, tanggapan dan persepsi kebebasan beragama merupakan hak setiap orang atas kesadaran dan keyakinannya sendiri memiliki kebebasan memeluk suatu agama tanpa tekanan dari pihak tertentu, seperti tabel 5 berikut :

Tabel 5. Persepsi dan Pandangan Masyarakat terhadap Kebebasan Beragama.

\begin{tabular}{|c|c|c|c|c|}
\hline $\begin{array}{c}\text { Persepsi dan } \\
\text { Pandangan } \\
\text { Kebebasan } \\
\text { Beragama }\end{array}$ & \multicolumn{2}{|c|}{ Pretest } & \multicolumn{2}{c|}{ Postest } \\
\cline { 2 - 5 } & F & \%) & F & $(\%)$ \\
\hline Sangat Setuju & 40 & 100 & 40 & 100 \\
\hline Kurang Setuju & 0 & 0 & 0 & 0 \\
\hline Tidak Setuju & 0 & 0 & 0 & 0 \\
\hline Jumlah & 40 & 100 & 40 & 100 \\
\hline
\end{tabular}

\section{Sumber : Hasil Olahan Kuesioner, 2019}

Data tabel 5 di atas menunjukkan bahwa persepsi dan pandangan masyarakat Kampung Rama terhadap kebebasan beragama sangat tinggi. Hal ini berdasarkan data pretest dan postest masing-masing $100 \%$ berpersepsi dan berpandangan bahwa kebebasan beragama sangat penting dan menjadi hak setiap warga negara untuk memilih dan menjalankan keyakinan masing-masing. Dalam masyarakat multikultural saling memahami budaya dan agama menjadi salah satu kunci keberhasilan berbangsa dan bernegara.

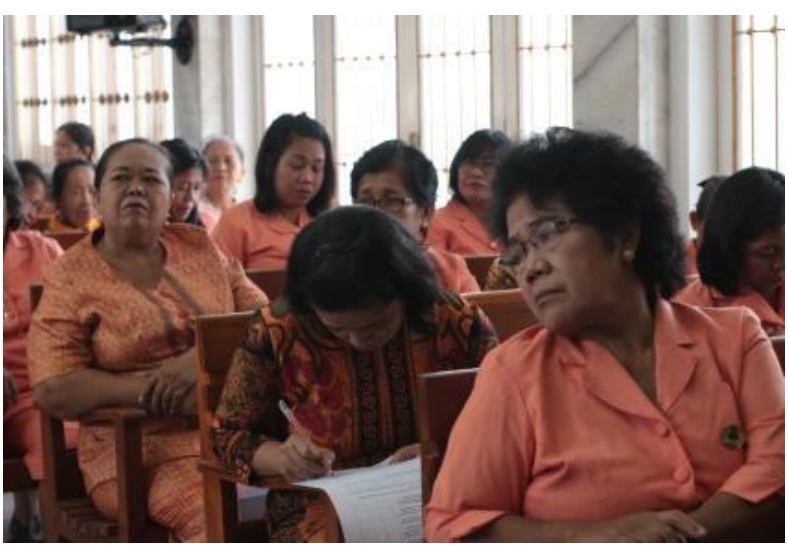

Gambar 2. Kegiatan Pretest Pelatihan Literasi Multikultural.

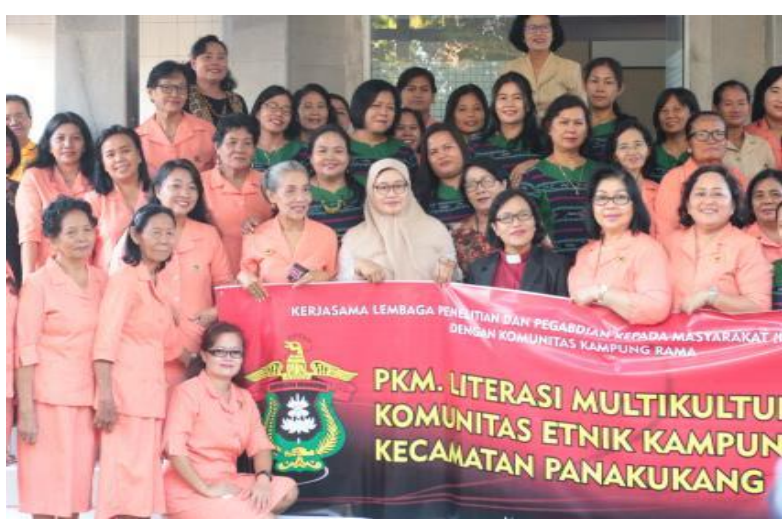

Gambar 3. Tim Pengabdian dan Komunitas Etnik Kampung Rama.

Pelatihan dan pemdampingan merupakan proses belajar mengajar dalam masyarakat multikultural. Individu belajar menjadi anggota masyarakat, dimana prosesnya tidak semata mata mengajarkan pola-pola perilaku sosial kepada individu tetapi juga individu tersebut mengembangkan dirinya atau melakukan proses pendewasaan dirinya. Secara jelas sosialisasi yang dilaksanakan mengacu pada pengertian sosialisasi menurut para ahli Charlotte Buchler bahwa sosialisasi adalah proses yang membantu individu-individu belajar dan menyesuaikan diri bagaimana cara hidup dan berpikir kelompoknya agar ia dapat berperan dan berfungsi dalam kelompoknya (Charlotte Buchler).

Selanjutnya Bruce J. Cohen mengemukakan bahwa sosialisasi adalah proses proses manusia mempelajari tata cara kehidupan dalam masyarakat (ways of life in society), untuk memperoleh kepribadian dan membangun kapasitasnya sehingga dapat berfungsi dengan baik sebagai individu.

Berdasarkan pemahaman pelatihan dan pendampingan merupakan proses dimana seseorang mempelajari polapola hidup dalam masyarakat sesuai dengan nilai nilai, norma dan kebiasaan yang berlaku untuk berkembang sebagai anggota masyarakat dan sebagai individu. Jadi, sosialisasi dapat memaksimalkan pemahaman pendidikan multikultural terhadap masyarakat etnik Toraja di Kampung Rama. Tujuannya agar tercipta harmonisasi bermasyarakat, berbangsa dan bernegara sehingga konflik-konflik antar etnik dapat dicegah dari awal.

\section{KESIMPULAN}

Pengabdian masyarakat di Kampung Rama Kecamatan Panakukang Kota Makassar dilakukan melalui metode pengajaran, dan pendampingan antar etnik. Dampak kegiatan yang menstimuli, mengarahkan, dan mempersuasi komunitas Etnik Kampung Rama telah meningkatkan pemahaman saling menghargai. Hasil pretest dan postest yang telah dilakukan sebelum dan setelah menunjukkan nilai postest lebih tinggi dari nilai pretest dalam pendidikan literasi multikultural memberikan kontribusi nyata terhadap agenda harmonisasi antar bangsa. Ha ini berimplikasi positif dalam konteks multikultural perbedaan keberagaman 
bangsa yang harus dibina dan dipertahankan.

Keberhasilan program literasi multikultural ini dapat ditindaklanjuti pada komunitas etnik yang mayoritas dan minoritas di kampung Rama. Program tersebut harus melibatkan unsur terkait, mulai dari Rukun Tetangga (RT), Rukun Warga (RW), kelurahan/desa, Kecamatan Panakukang dan Pemerintah Kota Makassar. Hal ini dapat menjadi tindakan preventif dalam memimalisasi konflik antar etnik yang dapat terjadi jika pemahaman multikulturalisme tidak ditanamkan mulai dari kanak-kanak hingga dewasa. Implikasi positif dari pendidikan multikultural harus terus diberdayakan secara berkelanjutan dan didukung semua pihak dan instansi yang terkait. Keberlajutan program ini dapat meningkatkan semangat pendidikan keberagaman dan kemajemukan masyarakat Multikultural, khususnya di Kota Makassar. Hal ini diperkuat oleh hasil yang telah diaplikasikan dalam bentuk pengabdian kepada masyarakat serta persatuan dan kesatuan bangsa.

\section{UCAPAN TERIMA KASIH}

Terima kasih atas Lembaga Penelitian dan Pengabdian Kepada Masyarakat (LPPM) Universitas Hasanuddin atas Program Kemitraan Unhas (PK-UH) Nomor Kontrak 678/UN4.21/PL.01.10/2019 Tanggal 6 Februari 2019. Terima kasih atas dukungan Departemen Ilmu Komunikasi, Tim Pengabdian, serta teman-teman mahasiswa Ilmu Komunikasi dalam pelaksanaan kegiatan Pelatihan dan Pendampingan Literasi Multikultural Komunitas Etnik Kampung Rama Kecamatan Panakukang Kota Makassar.

\section{DAFTAR PUSTAKA}

Bertens, K. Ekumenisme dan Multikulturalisme, Suara Pembaruan Daily, edisi Minggu, 16 - Mar - '08.

Bosse, M.C. Pola Pengembangan Kerukunan Berwawasan Multikultural dalam Pandangan Agama Hindu, SPEQLEN = Blog Nak Belog = The Truth Is Inside You. www.speqlen.co.id.

Christiani, T.K. (2009). Christian Education for Peace Building in the Pluralistic Indonesian Context. Dalam Carl Sterkens, Muhammad Machasin, Frans Wijsen (ed.). Religion, Civil Society and Conflict in Indonesia. Zurich: LIT VERLAG. (2012). Pendidikan Kristiani dengan Pendekatan Spiritualitas. Dalam Jozef Hehanusa dan Budyanto (ed.). Mendesain Ulang Pendidikan Teologi. Yogyakarta: Duta Wacana University Press.

http://lifestyle.kompasiana.com/catatan/2013/04/15/se buah-refleksi-dari- pengrusakan-gereja-diindonesia--551359.html (diakses tanggal 12 Maret 2018).

Ibrahim, R. (2013). Pendidikan Multikultural: Pengertian, Prinsip, dan Relevansinya dengan Tujuan Pendidikan Islam Universitas Nahdlatul Ulama (UNU) Surakarta, Jawa Tengah, Indonesia ADDIN, Vol. 7, No. 1, Februari 2013 https://media.neliti.com/media/publications/545
45-ID-pendidikan-multikultural-pengertianprin.pdf

Nurcahyono, O.H.H. Pendidikan Multikultural Di Indonesia: Analisis Sinkronis Dan Diakronis: Jurnal Pendidikan, Sosiologi dan AntropologiVol. 2 No.1 Maret 2018p.105-115. https://jurnal.uns.ac.id/habitus/article/viewFile/2 0404/15840.

Tilaar, H.A.R., (2004). Multikulturalisme: Tantangantantangan Global Masa Depan dalam Transformasi Pendidikan Nasional. Jakarta: Grasindo

Widjaya, P.S. (2004). Menuju Masyarakat Damai Sejahtera (Bahan Sarasehan dalam rangka Lustrum IV GKJ Condongcatur). Yogyakarta. 